\title{
POLA BAURAN MAHASISWA DALAM PEMANFAATAN RUANG PUBLIK TERBUKA KAMPUS
}

\author{
${ }^{1}$ Syaifullah, ${ }^{2}$ Hasdi Radiles \\ ${ }^{1}$ Program Studi Sistem Informasi, Fakultas Sains dan Teknologi, UIN SUSKA Riau, \\ J1. HR Soebrantas, KM. 18.5, No. 155, Simpang Baru, Pekanbaru, Indonesia, 28293. \\ ${ }^{2}$ Program Studi Teknik Elektro, Fakultas Sains dan Teknologi, UIN SUSKA Riau, \\ J1. HR Soebrantas, KM. 18.5, No. 155, Simpang Baru, Pekanbaru, Indonesia, 28293. \\ Email: ${ }^{1}$ Syaifullah@uin-suska.ac.id, ${ }^{2}$ hasdiradiles@uin-suska.ac.id
}

\begin{abstract}
ABSTRAK
Kampus UIN Suska Riau-Panam, merupakan pusat aktivitas perkuliahan tingkat sarjana (S1) yang terletak di perbatasan kota Pekanbaru. Peningkatan populasi civitas akademika, khususnya jumlah mahasiswa, membuat suasana kampus mulai terasa padat dan penuh sesak. Tujuan penelitian ini adalah untuk mengidentifikasi keberadaan ruang terbuka publik dan mengamati pola aktifitas bauran mahasiswa dalam memanfaatkan ruang publik ini. Hasil penelitian menunjukkan terdapat 29 titik ruang terbuka publik, dan sebagian besar terletak pada zona FST, Tarbiyah dan Syariah. Karakteristik ruang terbuka publik umumnya memanfaatkan kerindangan pohon. Sebagian ruang terbuka publik ini telah diinisiasi oleh pihak fakultas dan sebagian yang lain merupakan swadaya dari mahasiswa sendiri.
\end{abstract}

Kata Kunci: Pola bauran mahasiswa, ruang publik terbuka, kampus

\section{A. PENDAHULUAN}

Universitas Islam Negeri Sultan Syarif Kasim (UIN SUSKA) Riau merupakan salah satu universitas negeri yang terletak di kota Pekanbaru. UIN SUSKA memiliki dua kampus, yakni kampus sukajadi yang diperuntukan khusus untuk program Pasca Sarjana, dan kampus panam yang kemudian menjadi pusat administrasi dan perkuliahan strata-1 yang terdiri dari Sembilan fakultas. Dalam mengembankan misi nya, proses pembangunan dan pengembangan fasilitas diiringi dengan pertumbuhan civitas akademika yang sangat tinggi dari tahun ke tahun. Karena itu, dikhawatirkan akan dapat mengganggu kualitas layanan pendidikan dan kenyamanan yang dirasakan oleh segenap civitas akademika khususnya para mahasiswa.

Arti penting dari ruang terbuka publik bagi mahasiswa adalah sebagai wadah dalam mengembangkan keilmuan, kreatifitas ataupun soft skill ketika berinteraksi sesamanya [1]. Ruang terbuka publik pada kampus merupakan prasarana yang harus dimiliki suatu kampus ketika mahasiswanya sedang beraktifitas diluar jam-jam perkuliahan. Berbagai kebutuhan mahasiswa akan keberadaan ruang kampus di antaranya adalah prasarana pembelajaran, diskusi kelompok/privasi, tempat untuk bersantai atau melepas lelah dan lain sebagainya [2]. Umumnya pemanfaatan ruang kuliah ini terjadi sebelum/sesudah perkuliahan berlangsung atau ketika waktu istirahat siang.

Supaya pemanfaatan ruang terbuka publik ini berlaku sebagaimana fungsinya, pihak pengelola kampus harus mengendalikan dan memfasilitasi keberadaannya [1]. Perimbangan jumlah mahasiswa aktif harian dan kapasitas ruang publik yang tersedia harus tetap dijaga, agar mahasiswa merasa lebih nyaman dan bersemangat ketika berinteraksi sesamanya [3]. Beberapa ruang terbuka publik yang terindentifikasi, boleh jadi terbentuk pada zona atau area yang tidak dibenarkan, karena mengganggu aktifitas publik lainnya, sehingga perlu untuk dialihkan [4]. Oleh karena itu, perlu didefinisikan kriteria-kriteria ruang terbuka publik sesuai pola pemanfaatannya, dan pengelola kampus kemudian dapat mengembangkan struktur dan fasilitasnya [5][6].

Proses pengendalian keberadaan ruang terbuka publik ini, dipengaruhi oleh rasio populasi mahasiswa setiap fakultas yang ada di kampus UIN Suska - panam. Tidak meratanya jumlah populasi menyebabkan pola bauran mahasiswa pun menjadi menumpuk pada beberapa lokasi tertentu. Akibatnya, boleh jadi mahasiwa menjadi stress dan memilih untuk meninggalkan area kampus [7]. Secara tidak langsung dan mematikan kreatifitas dan pengembangan soft-skill mahasiswa karena berkurangnya interaksi mereka selama berada di kampus. Atau dengan kata lain gairah kehidupan kampus pun dapat memudar atau bahkan hilang.

Berangkat dari pemikiran tersebut, maka perlu untuk melakukan penelitian lebih jauh tentang pola bauran mahasiswa dalam memanfaatkan ruang terbuka publik ini. Tujuan dari penelitian ini adalah untuk mengindentifikasi ruang terbuka publik yang terbentuk pada area kampus UIN Suska Riau - Panam dan menganalisa pola bauran mahasiswa berdasarkan jenis-jenis kegiatan yang dilakukan. Pola bauran mahasiwa ini akan mudah untuk diamati jika menggunakan metoda pemetaan pada area kampus. Penelitian ini 
dilakukan dengan menggunakan pendekatan survey dan wawancara untuk mengetahui pola pemanfaatan ruang terbuka publik ini. Hasil penelitian diharapkan dapat dikembangkan lagi sehingga dapat menciptakan suasana kampus yang nyaman dan bermanfaat maksimal bagi mahasiswa dalam beraktifitas dan berinteraksi sesamanya.

\section{B. LANDASAN TEORI}

Pengertian dari ruang publik harus dimulai dari pemahanan spasial ruang yang dibedakan dalam tiga kategori yaitu [1]:

(1) fisik terdiri dari jalanan dan lapangan;

(2) fungsi meliputi sosial, rekreasi, komersil dan sirkulasi;

(3) kepemilikan, bersifat publik, privat atau kombinasi antara keduanya.

Penelitian tentang ruang publik dapat didekati secara konsep sebagai berikut [1]:

(1) membingkai kasus dan mengkonsepsualisasikan obyek penelitian;

(2) memilih fenomena, menentukan isu-isu yang menjadi fokus pertanyaan riset;

(3) melacak pola-pola data untuk memperkaya isu penelitian;

(4) teknik triangulasi untuk hasil observasi penting dan landasan interpretasi;

(5) menghadirkan alternatif penafsiran;

(6) merumuskan pernyataan sikap atau generalisasi tentang kasus.

\section{METODOLOGI PENELITIAN}

\section{C.1. Karakteristik Penelitian}

Ini harus dapat mengakomodasi keterbatasan waktu penelitian, mulai dari tahap pelaksanaan Penelitian ini dirancang untuk dapat diselesaikan dalam durasi 2-3 bulan sejak dinyatakan lulus tahap seleksi dan pencairan dana awal penelitian. Oleh karena itu, metoda-metoda yang dipilih dalam penelitian penelitian hingga kepada laporan akhir penelitian.

Tujuan penelitian ini dilakukan adalah untuk mendapatkan jawaban tentang keberadaan ruangruang publik, berdasarkan pola-pola bauran mahasiswa selama berada di area kampus. Keberadaan ruang publik ini boleh jadi ruang publik yang telah ada dan juga kandidat-kandidat ruang terbuka yang belum diperhatikan pihak pengelola kampus hingga saat ini. Keberadaan mahasiswa dalam penelitian ini adalah sebagai pemicu (subjek) terbentuknya ruang publik dan mengumpulkan opininya dalam menilai keberadaan ruang publik yang dimaksud.

Secara umum, jenis penelitian bersifat deskriptif, dimana informasi didapatkan dengan melakukan pengamatan terhadap gejala-gejala alamiah yang terjadi dilapangan (field research). Penentuan ruang publik dan lokasi pelaksanaan jajak pendapat, dilakukan dengan metoda survei (survey) pada titik-titik sampling yang telah diinvestigasi sebelumnya. Metoda ini dipilih untuk mendapatkan informasi yang lebih aktual hingga saat penelitian ini dilakukan. Pemilihan mahasiswa sebagai objek penelitian dilakukan dengan metoda multi-stage sampling, bersamaan ketika tim survey berada pada lokasi sampling (ruang publik). Metoda ini dipilih untuk mendapatkan opini mahasiswa sebanyak mungkin dengan waktu pengamatan yang terbatas.

\section{C.2. Teknik Sampling}

\section{C.2.1. Teknik Pemilihan Existing/Kandidat Ruang Publik}

Ruang publik diidentifikasi berdasarkan beberapa kriteria berikut ini:

(1) tempat berkumpulnya mahasiswa dengan jumlah minimum 3 orang, untuk mengeliminasi subjektifitas terhadap ruang public;

(2) durasi pemanfaatan ruang publik tersebut \pm 15 menit, untuk mengeliminasi kemungkinan adanya pertemuan yang bersifat accidental;

(3) ruang publik yang dimaksud bukan merupakan bagian dari fasilitas akses, seperti jalan dan trotoar, agar pengembangan ruang publik dapat dilakukan dikemudian hari.

Pengamatan terhadap pola bauran mahasiswa dalam memanfaatkan ruang publik ini dilakukan dalam 3 x 5 hari, yaitu ketika hari-hari perkuliahan berlangsung. Dalam satu hari, ruang publik diamati dalam 3 kriteria waktu, yakni

(1) Pagi hari $(08.00-10.00)$

(2) Siang hari $(10.00-14.00)$

(3) Sore hari $(14.00-16.00)$

\section{C.2.2. Teknik Pemilihan mahasiswa sebagai objek penelitian}

Sebagaimana halnya proses pengamatan ruang publik, tim survey juga dapat melakukan jajak pendapat pada lokasi ruang publik yang sedang di amati, sesuai dengan jam-jam yang telah ditentukan. Teknik pemilihan mahasiswa dilakukan secara random, mengingat kemungkinan untuk melakukan jajak pendapat di lapangan juga bersifat random. Adapun target jumlah responden yang berada pada lokasi, diinginkan sebanyak mungkin untuk mengakomodasi variasi opini mahasiswa terhadap ruang publik tersebut.

\section{C.3. Metoda Pengumpulan Data}

Data yang dikumpulkan dalam penelitian ini terdiri dari data pengamatan dan data hasil jajak pendapat dari mahasiswa yang berada pada ruang publik. Pengamatan terhadap ruang publik mencakup karakteristik ruang publik (dilakukan saat investigasi ruang publik), jumlah pengguna ruang publik dan data opini mahasiswa terhadap ruang publik. 
Investigasi ruang publik dilakukan dengan cara mendatangi seluruh area yang dapat diakses mahasiswa yang memenuhi kriteria yang telah ditetapkan pada sub-bab sebelumnya. Hasil penemuan tentang karakteristik ruang publik kemudian diidentifikasi dan di data.

Sedangkan data opini didapatkan dengan melakukan wawancara untuk mendapatkan jawaban yang disediakan. Jawaban ini kemudian diakumulasi untuk mendapatkan statistik dari masing-masing ruang publik yang sedang diamati. Adapun pertanyaan dan jawaban yang disediakan untuk proses wawancara adalah sebagai berikut:

(1) Apakah jenis kegiatan yang anda lakukan pada ruang publik ini?

(a) Kegiatan yang menunjang perkuliahan.

(b) Kegiatan extra-kemahasiswaan diluar perkuliahan.

(c) Kegiatan bebas mengisi waktu luang.

(2) Seberapa sering anda menghabiskan waktu di ruang publik ini?

(a) Jarang; 1-2 kali seminggu dengan durasi kumulatif kurang dari satu jam

(b) Sedang; 3-4 kali seminggu dengan durasi kumulatif kurang dari 2-4 jam

(c) Sering; lebih dari 4 kali seminggu dengan durasi kumulatif lebih dari 4 jam

(3) Bagaimanakah pendapat anda mengenai ruang publik ini?

(a) Tidak layak; fasilitas/ akses/ kenyamaan tidak layak untuk berkumpul.

(b) Cukup layak; fasilitas/ akses/ kenyamanan terbatas untuk berkumpul.

(c) Sangat layak; fasilitas/ akses/ kenyamanan mendukung untuk berkumpul.

\section{ANALISA DAN PEMBAHASAN}

\section{D.1. Identifikasi \& Karakteristik}

Proses identifikasi membagi wilayah pencarian ruang terbuka publik menjadi sepuluh zona sebagaimana yang tergambar pada Gambar 1 . Dalam proses identifikasi, ditemukan 29 titik ruang terbuka publik yang dimanfaatkan oleh mahasiswa UIN SUSKA Riau.

\section{D.1.1. Zona Fakultas Sains dan Teknologi (FST)}

Ruang terbuka publik ini diinisiasi oleh pihak fakultas dengan memberikan fasilitas meja dan kursi yang layak. Kerindangan pepohonan merupakan alasan pemilihannya sebagai sarana belajar bagi para mahasiswa sebelum/sesudah perkuliahan berlangsung. Namum fasilitas komunikasi seperti wi-fi dan sinyal mobile phone terbatas dan hanya melayani pelanggan Telkomsel. Ide pengadaan dan pemilihan lokasi ruang terbuka publik ini dirasakan tepat dan selalu dimanfaatkan oleh para mahasiswa. Penambahan kapasitas meja dan tempat duduk sangat diharapkan karena intensitas pemanfaatan yang tinggi. Parkiran motor karyawan FST sisi kiri bisa dilihat pada Gambar 2.

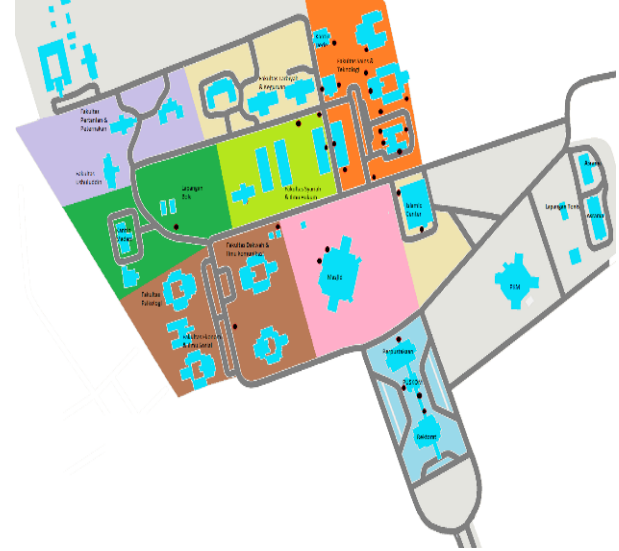

Gambar 1. Hasil identifikasi ruang terbuka publik mahasiswa pada kampus UIN Suska - Panam

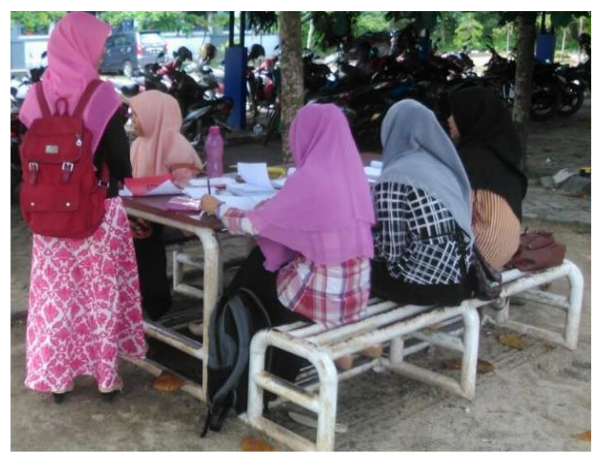

Gambar 2. Parkiran motor karyawan FST sisi kiri

\section{(1) FST pintu kanan}

Ruang terbuka publik ini juga merupakan inisasi dari pihak fakultas. Suasana pohon yang rindang dan akses ke dua gedung perkuliahan yang dekat menjadikan lokasi ini sangat cocok untuk mahasiswa yang ingin berdiskusi dan belajar sebelum/sesudah perkuliahan. Tetapi fasilitas komunikasi wi-fi dan mobile yang terbatas perlu untuk segera diatasi, agar proses belajar dapat memanfaatkan fasilitas internet. Penambahan kapasitas meja dan kursi sangat diharapkan mengingat tingginya intensitas pemanfaatan ruang terbuka publik ini.

\section{(2) FST Gedung Baru Pintu Kiri}

Ruang terbuka publik ini sering dimanfaatkan mahasiswa yang menunggu perkuliahan yang akan berlangsung. Keberadaan ruang terbuka ini jelas menganggu akses keluar masuk gedung dari sisi kiri, setelah ramainya kendaraan yang parkir tak beraturan. Dalam hal ini mahasiswa tidak memiliki pilihan lain selain berbaur dengan cara berdiri untuk menghindari teriknya panas di siang hari.

Pihak pengelola kampus seharusnya menyediakan ruang terbuka publik di area ini mengingat kurangnya lokasi yang rindang dan nyaman untuk berdiskusi dan belajar bagi para mahasiswa. Kebutuhan ruang terbuka publik baru pada lokasi ini bersifat segera. 


\section{(3) Teras depan Lab FST}

Dalam masa-masa pratikum, ruang terbuka publik sering muncul pada teras depan lab FST. Mahasiswa terpaksa menggunakan lokasi ini sebelum/sesudah pratikum berlangsung. Akses dan kondisi yang yang nyaman merupakan alasan utama pemanfaatan ruang terbuka publik ini. Namun keberadaan ruang ini telah menyalahi estitika keindahan, dan oleh karena itu pihak pengelola harus memberikan alternatif ruang terbuka publik untuk menampung mahasiswa yang akan/sudah.

\section{(4) Sisi Kiri Lab FST}

Ruang terbuka publik ini cenderung digunakan mahasiswa untuk kegiatan bebas dan merokok. Lokasinya yang rindang tetapi tersembunyi, menjadikan ruang terbuka ini hanya diakses rutin oleh beberapa individu saja. Hanya tersedia beberapa kursi bekas dengan kondisi yang semerawut oleh parkir motor bebas menyulitkan pengembangan ruang terbuka publik ini menjadi lebih baik. Pihak pengelola dapat menilai lebih bijak tentang keberadaan ruang terbuka publik ini lebih lanjut.

\section{(5) Belakang Lab FST}

Ruang terbuka publik ini diinisiasi oleh pihak fakultas FST dengan menyediakan kursi dan meja. Meskipun tujuan awalnya sebagai tempat untuk berdiskusi dan belajar mahasiswa, tetapi umumnya digunakan sebagai tempat untuk bersantai dan melepas lelah. Tempatnya yang tersembunyi kadang digunakan juga sebagai area untuk merokok. Tetapi kebersihan lokasi perlu untuk diperhatikan, karena adanya tumpukan sampah disekitar ruang terbuka publik ini.

(6) Post Satpam Akses Keluar/Masuk Area FST Ruang terbuka publik ini sebelumnya diperuntukan bagi satpam dalam mengendalikan arus kendaran keluar/masuk FST. Semenjak tidak ada lagi satpam yang bertugas, ruang terbuka ini sering dimanfaatkan mahasiswa untuk kegiatan bebas. Jika keberadaan ruang terbuka publik ini menyalahi estetika, pihak pengelola harus mengantisipasi proses pemanfaatan ruang terbuka publik secara berkelanjutan.

\section{(7) Depan Gedung PSI}

Ruang terbuka publik yang tercipta di depan gedung psi ini bersifat spontanitas ketika jam-jam perkuliahan padat yang dilaksanakan di gedung ini. Keberadaan ruang ini dirasakan menyalahi estitika keindahan dan menganggu akses keluar masuk bagi dosen/mahasiswa lainnya yang hendak melaksanakan perkuliahan. Pola bauran mahasiswa umumnya dengan berdiri atau memanfaatkan ruang kosong diserambi gedung. Kebutuhan ruang terbuka publik yang lebih layak dan nyaman sebagai tempat alternatif bersifat segera dan butuh perhatian lebih dari pihak pengelola kampus. Gedung PSI Samping Kiri dapat dilihat pada Gambar 3.

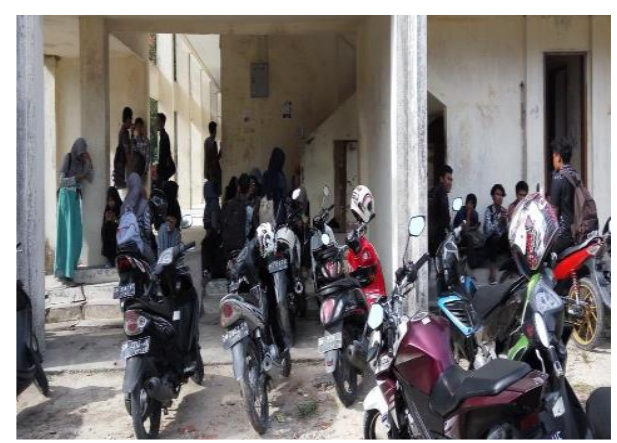

Gambar 3. Gedung PSI samping kiri

\section{D.1.2. Zona Fakultas Tarbiyah}

(1) Sisi Kanan Perpustakaan Tarbiyah

Keberadaan ruang terbuka publik ini adalah swadaya mahasiswa dengan memanfaatkan selasar gedung perpustakaan tarbiyah pada sisi kanan. Ruang yang digunakan bercampur dengan parkiran mobil dan motor sehingga keberadaannya menyalahi estetika keindahan. Pihak pengelola harus menfasilitasi pengadaan ruang terbuka publik yang baru dengan mengatur keberadaan parkir dan tempat bagi mahasiswa yang berbaur.

(2) Sisi Kiri Perpustakaan Tarbiyah

Keberadaan ruang terbuka publik ini adalah swadaya mahasiswa dengan memanfaatkan selasar gedung perpustakaan tarbiyah pada sisi kanan. Meskipun ruang terbuka ini tampak bercampur dengan parkiran mobil dan motor, tetapi pihak pengelola kampus dapat mengaturnya agar lebih nyaman dan indah. Kondisi yang rindang mendukung untuk dijadikannya lokasi sebagai ruang terbuka publik dengan fasilitas tempat duduk dan meja yang lebih memadai.

\section{D.1.3. Zona Fakultas Syariah}

(1) Samping Gedung Syariah

Ruang terbuka publik ini timbul karena lokasi yang nyaman dan rindang, dengan memanfaatkan pot-pot tanaman sebagai kursi. Mengingat minimnya ruang terbuka publik pada lokasi ini, pihak pengelola harus dapat mengembangkannya menjadi ruang terbuka publik dengan fasilitas yang lebih layak.

(2) Depan Gedung Syariah

Ruang terbuka publik ini berada pada pintu masuk gedung syariah yang dilengkapi dengan papan tempat informasi kemahasiswaan. Ruang publik ini selalu dikunjungi mahasiswa yang hendak atau telah melakukan perkulihan di gedung ini. Tidak tersedianya kursi dan meja, mengharuskan mahasiwa untuk berdiri atau duduk di anak tangga pintu masuk gedung. Pihak 
pengelola kampus seharusnya mengembangkan ruang terbuka publik ini dengan memperhatikan estetika keindahan kampus.

(3) Sisi Belakang Tarbiyah (Kebun Sawit)

Lokasi ini sering dimanfaatkan mahasiswa sebagai ruang terbuka publik untuk kegiatan santai dan extra kemahasiswaan. Kondisi yang rindang dan sejuk serta akses yang mudah menjadikannya sebagai ruang terbuka yang ideal. Oleh karena itu pihak pengelola kampus diharapkan untuk dapat menfasilitasi ruang terbuka publik ini untuk fasilitas meja dan kursi, sehingga mahasiswa tetap dapat memanfaatkannya dengan lebih nyaman.

\section{D.1.4. Zona Fakultas Ekonomi}

Pada zona ini terdapat dua ruang terbuka publik pada zona ini. Keberadaan mahasiswa di luar perkuliahan cenderung menetap di dalam gedung perkuliahan dan sebagian besar memilih untuk ke kantin atau keluar area kampus.

(1) Depan gedung Fekonsos

Ruang terbuka publik ini merupakan swadaya mahasiswa dengan tujuan khusus. Kegiatan extra kemahasiswaan melatarbelakangi pembuatan ruang terbuka publik ini. Suasana rindang pepohonan dengan fasilitas kursi dari ruang perkuliahan cukup membuat mahasiswa nyaman dalam melakukan kegiatannya. Untuk menjaga estetika keindahan, pihak pengelola kampus mestinya memberikan fasilitas yang lebih baik seperti gazebo ataupun posko-posko kemahasiswaan.

\section{(2) Kantor Menwa}

Keberadaan ruang terbuka publik ini bersampingan dengan kantor Menwa. Umumnya pola bauran mahasiswa adalah kegiatan extra kemahasiswaan. Meskipun fasilitas meja dan kursi telah tersedia, tetapi kelihatan keindahan dan kerapihannya kurang dan perlu untuk dibenahi, mengingat ruang terbuka publik ini berada pada tepi jalan akses kampus.

\section{D.1.5. Zona Lapangan Bola}

Pada zona lapangan bola hanya ditemukan satu lokasi ruang terbuka publik dengan memanfaatkan area yang rindang dengan fasilitas yang minim berupa dua buah kursi. Zona lapangan bola dapat dilihat pada Gambar 4.

Ruang terbuka publik ini merupakan swadaya mahasiswa untuk kebutuhan extra kemahasiswaan. Lokasi ruang terbuka ini dilatarbelakangi oleh rindangnya pepohonan dan beralaskan rumput. Peningkatan fasilitas ruang terbuka ini diperlukan untuk menampung minat mahasiwa dalam melakukan kegiatan extra kemahasiswaan.

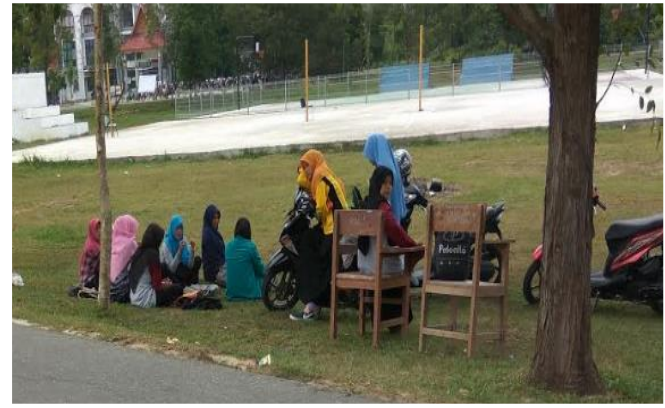

Gambar 4. Lapangan bola

\section{D.1.6. Zona Rektorat}

Terdapat dua ruang terbuka publik dalam zona ini, yaitu lorong puskom dan serambi Perpustakaan UIN SUSKA.

(1) Lorong Rekotrat-Puskom-Perpustakaan

Dari semua ruang terbuka publik yang dimanfaatkan oleh mahasiswa, hanya ruang terbuka inilah yang memiliki fasilitas dan kondisi yang terbaik. Selain kondisi yang nyaman dan sejuk, meja dan kursi telah disediakan dengan fasilitas wifi untuk internet. Umumnya mahasiswa yang mengunjungi ruang terbuka publik ini adalah mereka yang sedang menjalankan tugas akhir dan membutuhkan fasilitas internet. Intensitas penggunaan ruang terbuka publik ini sangat padat pada saat jam kerja.

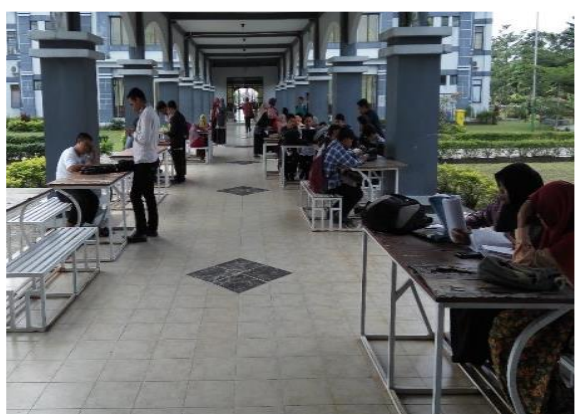

Gambar 5. Lorong Rektorat-Puskom-Perpustakaan

\section{(2) Sisi kanan Puskom}

Ruang terbuka publik ini memanfaatkan keteduhan dari serambi kanan puskom. Pola bauran mahasiswa terjadi pada hari-hari kerja dengan kegiatan duduk-duduk santai. Meskipun lokasi ruang terbuka ini nyaman dan bersih, tetapi keberadaannya mengurangi estetika keindahan. Pihak pengelola dapat mengatasinya dengan memberikan fasilitas tempat duduk yang lebih nyaman bagi mahasiswa.

\section{(3) Serambi Perpustakaan UIN SUSKA}

Meskipun ruang perpustakaan terasa nyaman, tetapi beberapa mahasiswa menjadikan serambi perpustakaan UIN SUSKA sebagai tempat untuk duduk-duduk santai. Keberadaan ruang terbuka ini jelas menyalahi estetika keindahan perpustakaan UIN SUSKA. Tindakan yang dapat dilakukan 
adalah dengan menyempurnakan ruang terbuka publik ini dengan menyediakan kursi-kursi agar mahasiswa dapat duduk dan kelihatan lebih sopan.

\section{D.1.7. Zona Masjid UIN SUSKA Riau}

Ruang terbuka publik ini sering diminati mahasiswa sebelum/sesudah pelaksanaan sholat dzuhur. Umumnya mahasiswa berbaur dalam melepaskan lelah sambil mengobrol bebas. Tetapi kadang beberapa mahasiswa juga menjadikannya sebagai tempat untuk berdiskusi dan belajar. Keberadaan bauran mahasiswa ini jelas menganggu akses keluar/masuk jamaah gedung lainnya. Intensitas bauran mahasiswa akan lebih ramai lagi ketika hari-hari sibuk tertentu.

\section{D.1.8. Zona Islamic Center}

(1) Depan serambi Islamic Center

Ruang terbuka publik yang terbentuk pada anak tangga pintu utama Islamic center ini, sering dimanfaatkan mahasiswa dengan kegiatan bebas. Ruang terbuka publik ini timbul sesekali saja dalam seminggu ketika kegiatan-kegiatan tertentu. Dalam hal ini jelas keberadaan ruang terbuka tersebut mengurangi estetika keindahan suasana depan Islamic center.

(2) Sisi kanan Islamic Center

Ruang terbuka publik sering terjadi pada sisi kanan Islamic center. Mahasiswa memanfaatkan suasana teduk pada teras dengan pola bauran santai. Pemanfaatan ruang terbuka publik ini sifatnya sementara sebagai tempat untuk menunggu atau mengobrol bebas. Keberadaan ruang terbuka tersebut semakin memperumit akses jalan yang juga digunakan mahasiswa sebagai lahan parkir yang semrawut.

\section{E. POLA BAURAN MAHASISWA}

Dari hasil identifikasi, ditemukan 29 titik ruang terbuka publik pada area kampus UIN Suska Riau. Berdasarkan hasil wawancara langsung, dari 29 titik ruang terbuka ini, 15 titik ruang terbuka publik dimanfaatkan oleh mahasiswa FST (Fakultas Sains \& Teknologi), dan 9 titik oleh mahasiswa dari FTK (Fakultas Tarbiyah dan Keguruan). Sedangkan pada fakultas lainnya hampir tidak terbentuk ruang terbuka publik bagi mahasiswa, kecuali di beberapa titik. Selain itu, unit Puskom dan Masjid merupakan alternatif ruang terbuka publik yang terbentuk pada selasar bangunan. Pola bauran mahasiswa dalam mengakses ruang terbuka public dapat dilihat pada Gambar 6.

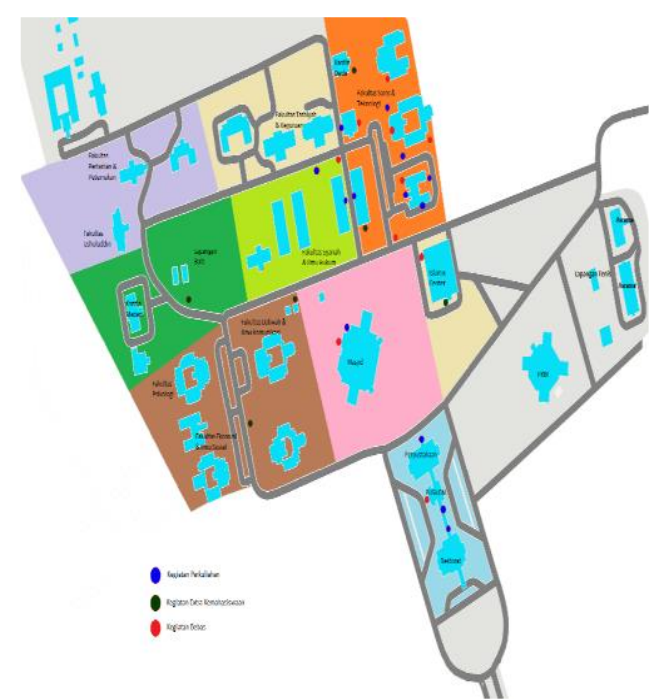

Gambar 6. Pola bauran mahasiswa dalam mengakses ruang terbuka publik

Hampir 55\% jumlah pengunjung ruang terbuka publik terjadi pada area FST, FTK dan FSIH. Sedangkan pada unit Puskom dan Masjid, jumlah pengunjung hanya mencapai $25 \%$ dari total populasi pengunjung. Hal ini diperlihatkan oleh grafik pada Gambar 7.

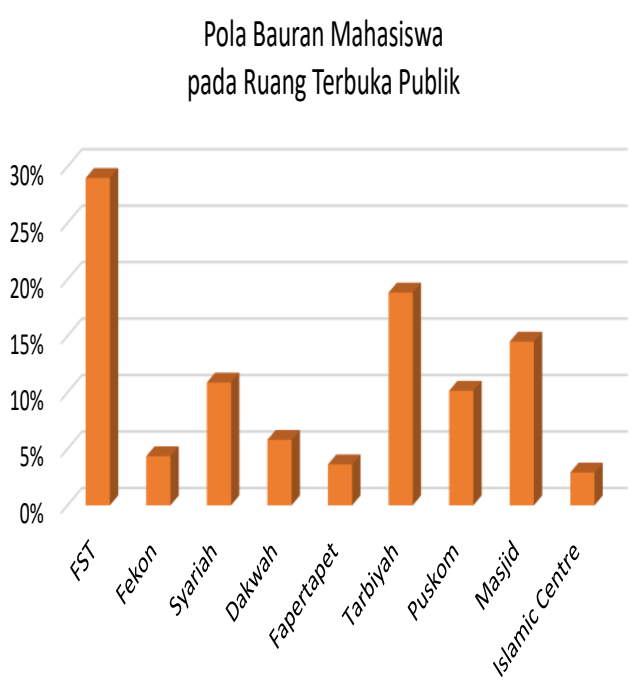

Gambar 7. Grafik distribusi mahasiswa yang berbaur dalam memanfaatkan ruang terbuka publik

Dari perhitungan statistik, ruang terbuka publik ini dimanfaatkan untuk berbagai kegiatan mencakup: kegiatan penunjang perkuliahan, kegiatan extra mahasiswa, dan kegiatan santai. Distribusi bauran mahasiswa berdasarkan tujuan pemanfaatannya diberikan oleh Gambar 6, sedangkan pola pemanfaatannya diberikan oleh Gambar 8 . 
Pola Bauran Mahasiswa (172 Responden)

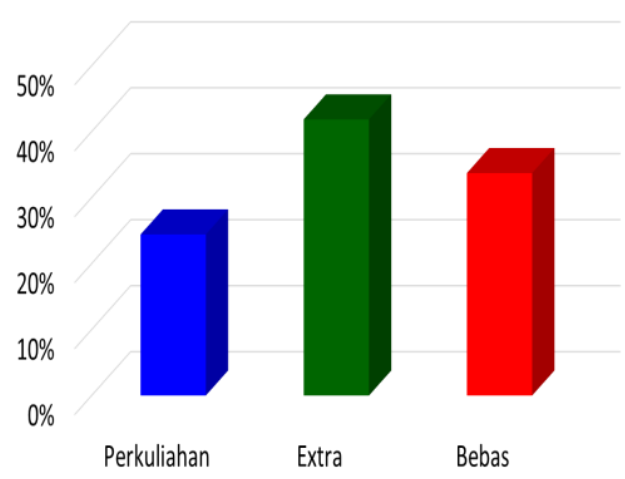

Gambar 8 Pola pemanfaatan ruang terbuka publik

Dapat dilihat bahwa mahasiswa cenderung memanfaatkan ruang terbuka publik sebagai sarana pembelajaran, terlihat jelas pada area FST dan sekitarnya. Sedangkan ruang terbuka publik lainnya terbentuk karena kebutuhan khusus diluar kegiatan perkuliahan.

\section{F. TINGKAT KEPADATAN DAN KELAYAKAN RUANG TERBUKA PUBLIK}

Tingkat kelayakan ruang terbuka publik pada umumnya mengandalkan keteduhan dari pepohonan yang ada disekitarnya. Beberapa diantaranya telah mulai disediakan kursi dan meja khusus oleh fakultas atau unit tertentu seperti FST pada sisi parkiran motor dan pada selasar PUSKOM. Fasilitas ini memungkinkan mahasiswa untuk mengakses Laptop dan menulis dengan nyaman sehingga ruang terbuka publik ini cenderung dimanfaatkan untuk kegiatan penunjang perkuliahan. Khusus pada selasar Puskom, fasilitas wi-fi (internet) sangat berguna dan dimanfaatkan sepenuhnya oleh mahasiswa yang membutuhkan akses ini.

Meskipun demikian, akses telekomunikasi mobile tetap menjadi kendala utama bagi mahasiswa untuk berkomunikasi. Umumnya kekuatan sinyal komunikasi (Telkomsel) hanya berkisar antara $-97 \mathrm{~s} / \mathrm{d}-110 \mathrm{dBm}$ saja. Dengan kata lain, mahasiswa hanya dapat menggunakan akses komunikasi suara dan tidak dapat menggunakan modem sendiri, sehingga sangat bergantung pada fasilitas wifi yang ada untuk mengakses internet.

Ruang terbuka publik lainnya terbentuk atas swadaya mahasiswa sendiri, dengan mengupayakan kursi-kursi yang bisa mereka dapatkan. Meskipun tergolong teduh dari panas, tetapi tidak dapat mengatasi permasalahan hujan. Ruang terbuka publik ini umumnya terbentuk untuk kepentingan kegiatan extra mahasiswa seperti himpunan dan kelompok-kelompok khusus lainnya sebagaimana yang diperlihatkan pada Gambar 6. Ciri-ciri dari ruang terbuka publik ini umumnya berada di pinggiran jalan dan mudah terlihat dari kejauhan.

Ruang terbuka publik yang memiliki fungsi sebagai tempat obrolan bebas atau santai, umumnya terbentuk pada lokasi-lokasi yang lebih rindang dan mengandalkan struktur bangunan yang telah ada, termasuk pot-pot tanaman yang tidak diperuntukan sebagai tempat duduk. Meskipun keadaannya tidak dipersiapkan untuk menjadi ruang terbuka publik, tetapi memungkinkan untuk kembangkan menjadi tempat yang lebih layak oleh pihak pengelola. Keberadaan ruang terbuka publik ini umumnya diminati oleh mahasiswa yang ingin menghabiskan waktunya di kampus sebelum balik ke rumahnya masing-masing.

Meskipun ruang terbuka publik ini merupakan kebutuhan penting mahasiswa, tetapi beberapa ruang terbuka publik terbentuk pada lokasi yang tidak dibenarkan. Contoh ruang terbuka publik ini adalah seperti berkumpulnya mahasiswa di pintu utama fakultas dengan duduk berkelompok di teras atau pada selasar masjid yang dapat mengganggu akses orang-orang yang hendak keluar/masuk gedung. Fenomena menggunakan selasar masjid untuk kegiatan penunjang perkuliahan sering terjadi pada jam sholat dzuhur dan ashar, di mana mahasiswa memanfaatkan kondisi lantai yang bersih dan nyaman untuk mengerjakan tugas-tugas perkuliahan. Meskipun sifat dari ruang terbuka publik tersebut temporal, tetapi dapat mengganggu aktifivitas lainnya. Hal ini terjadi karena kurangnya daya tampung ruang terbuka publik yang ada saat ini untuk dapat dimanfaatkan oleh mahasiswa dalam berinteraksi.

Tingkat kepadatan penggunaan ruang terbuka publik terkosentarasi pada area FTK-FST dan FSIH. Hal ini masuk akal mengingat populasi mahasiswa aktif hariannya terpusat pada area ini. Sifat ruang terbuka publiknya umumnya permanen dan selalu dimanfaatkan mahasiswa. Sedangkan pada fakultas dan unit lainnya, mahasiswa lebih memilih untuk tetap tinggal di gedung-gedung meskipun kurang nyaman dan penuh sesak. Sementara itu, luapan mahasiswa lainnya akan berpindah ke gedung-gedung kantin disekitarnya atau memilih untuk pergi keluar dari areal kampus. Ketidak-nyamanan ini membuat mahasiswa lebih cenderung menghabiskan waktunya untuk kegiatan santai atau melepas lelah.

Dari hasil wawancara, $80 \%$ dari total mahasiswa yang ditemui merasakan kurangnya keberadaan ruang terbuka publik dan kewalahan dalam mencari tempat untuk berinteraksi sesamanya. Dari semua mahasiswa yang diwawancara, $60 \%$ diantaranya hanya dapat mengakses ruang terbuka publik $1-2$ kali dalam seminggu dengan durasi 1-2 jam per minggunya, dan 25\% menyatakan dapat mengakses 2-4 kali perminggu dengan durasi total 4-6 jam. Sedangkan sisanya $15 \%$, dapat mengakses ruang terbuka 
publik ini lebih dari 5 kali perminggu. Dari statistik ini, dapat diduga bahwa sebagian besar mahasiswa kesulitan dalam mengakses ruang terbuka publik di kampus UIN Suska Riau karena kepadatan kapasitas atau karena alasan lainnya.

\section{G. KESIMPULAN}

Berdasarkan pembahasan hasil pengamatan dan wawancara, dapat disimpulkan sebagai berikut:

(1) Ruang terbuka publik yang terbentuk pada area kampus UIN Suska Riau - Panam berjumlah 29 titik (spot) yang terkosentrasi pada area FTK - FSK dan FSIH;

(2) Umumnya karakteristrik ruang terbuka publik terbentuk pada pohon-pohon yang rindang, tetapi bermasalah ketika keadaan hujan;

(3) Ruang terbuka publik yang dimanfaatkan untuk kegiatan penunjang perkuliahan telah dibentuk langsung oleh pihak kampus;

(4) Selain pada selasar PUSKOM, ruang terbuka publik lainnya umumnya belum mendapatkan fasilitas wi-fi dan sarana telekomunikasi yang terbatas pada komunikasi suara;

(5) Ruang terbuka publik yang dimanfaatkan untuk kegiatan extra mahasiswa, terbentuk oleh swadaya mahasiswa sendiri.

(6) Beberapa ruang terbuka publik yang terbentuk menyalahi aturan dan estetika keindahan, karena mengganggu aktivitas orang yang keluar/masuk bangunan.

(7) Mahasiswa memilih untuk menghabiskan waktunya di gedung-gedung perkuliahan, kantin atau meninggalkan area kampus, akibat padatnya penggunaan ruang terbuka publik yang ada.

(8) Ketidaknyamanan ruang terbuka publik menurunkan gairah mahasiswa untuk berinteraksi dalam kegiatan penunjang perkuliahan.

(9) Jumlah dan kapasitas ruang terbuka publik saat ini belum memadai dan perlu untuk ditambah proporsional terhadap populasi masing-masing fakultas.

\section{REFERENSI}

[1] Gunawan, Rony Sunaryo. 2009. Perubahan Setting Ruang dan Pola Aktivitas Publik di Ruang Terbuka Kampus UGM. Seminar Nasional Riset Arsitektur dan Perencanaan (SERAP) 1. Yogyakarta: Universitas Gadjah Mada.

[2] Dyah, Apriliana Wardhani \& Artiningsih. 2009. Studi Pola Pemanfaatan Ruang Terbuka Publik berdasarkan lifesty Mahasiswa di Kampus Universitas GajahMada Yogyakarta. Jurnal Tata Loka Volume 11 No 1 Februari 2009 hal 14-27. Yogyakarta: Universitas Gadjah Mada.

[3] Purnomo, Yudi, dkk. 2014. Konsep Ruang Terbuka Publik Mahasiswa Sebagai Penghubung Antar Unit di Universitas TanjungPura. Langkau Betang, Vol. 1/No. 1/2014. Tanjungpura: Universitas Tanjungpura.

[4] Ramdlani, Subhan, dkk. 2013. Karakter dan Pola Tata Ruang Kawasan Sekitar Kampus Universitas Brawijya. Jurnal RUAS, Volume 11 No 1, juni 2013, ISSN 1693-3702. Malang: Universitas Brawijaya.

[5] Fidiawati. 2015. Pengaruh Kondisi Fisik Ruang Terhadap Kenyamanan Termal Ruang Publik Di Kampus Universitas Negeri Malang. Tesis. Malang: Universitas Negeri Malang.

[6] Rihadi, Rahadian, dkk. 2010. Studi Ruang Komunal Bagi Mahasiwa di Kampus - Kampus di Kota Medan. Laporan Penelitian Mahasiswa Kreatif - Dikti. Medan: Universitas Sumatra Utara.

[7] Priyadi, Adam. 2014. Identifikasi Kebutuhan Ruang Publik Kampus UPI Berdasarkan Aktivitas Mahasiswa. Tesis. Bandung: Universitas Pendididikan Indonesia. 